\title{
New Electrocatalysts for Electro-Oxidation of Methanol Prepared by Bönnemann's Method
}

\author{
A. Oliveira Neto, E.G. Franco, E. Aricó, M. Linardi \\ Instituto de Pesquisa Energéticas e Nucleares - Centro de Ciência e \\ Tecnologia de Materiais - Laboratório de Células a Combustivel PEM, \\ Travessa R, No. 400, SP, Brasil
}

Received 26 December 2002; accepted 4 March 2004

\begin{abstract}
$\mathrm{Pt}-\mathrm{Ru} / \mathrm{C}, \mathrm{Pt}-\mathrm{Dy}$ and Pt-Ru-Mo/C electrocatalysts prepared by Bönnemann's method have been studied as porous thin films on high surface area carbon electrodes, in order to evaluate their electroactivity on CO desorption in PEM fuel cells. For comparison electrode precursor powders with and without thermal treatment were considered.

Cyclic voltammetry showed that addition of Mo in the well-established $\mathrm{Pt} / \mathrm{Ru}$ system is very promising for methanol oxidation. In order to compare the electroactivity of different catalysts a normalization procedure based on the amount of Pt was used.
\end{abstract}

Keywords: platinum; electrocatalysis; catalyst; voltammetry; fuel cell.

\section{Introduction}

The need for more efficient energy conversion is presently evident as the world fossil fuel sources become scarcer and the cost of the fuels rises. Moreover, the urgent necessity of pollution reduction in large urban centers imposes the use of non-polluting fuels, like hydrogen and renewable primary fuels in large scale [1]. Fuel cells have shown to be an interesting and very promising alternative to solve the problem of clean electric power generation with high efficiency [1].

According to a recent review from a fuel company "The question of fuel choice, for fuel cell vehicles remains an open one" [2]. For stationary applications the

\footnotetext{
* Corresponding author. E-mail address: neto.almir@bol.com.br
} 
question is also pertinent. Research for the best solution may lead to the definition of more convenient local options. As concluded, the "best" fuel solution is strongly influenced by the local conditions in the country, or region being considered [3].

When considering the combustion heat per mass, hydrogen presents a large advantage over other fuels, but when the number of available electrical charges per mass are compared the advantage is not significant. Hydrogen liquefaction would require an energy-spending equivalent of about $30 \%$ of its calorific power [4]. Because of this, hydrogen gas utilization has been considered, as safer techniques for handling it have been developed. Hydrogen production implies in additional questions.

Some organic substances are considered very promising as alternative fuels for electrochemical energy conversion. These substances are oxidized on the anode while pure oxygen, or from ambient air, is reduced on the cathode in low temperature fuel cells. Recently the use of methanol in electrocatalytic processes has received great attention in many research groups, justified by the development of more efficient and less polluting electrochemical energy conversion systems. The oxidation of small organic molecules, like methanol on a Pt electrode is followed by the formation of intermediates, like $\mathrm{CO}$, which are strongly adsorbed on the catalyst surface, reducing considerably its electroactivity. Electrochemical experiments have shown that carbon dioxide was produced in the oxidation of methanol on polycrystalline platinum electrodes [58]. CO tolerance is therefore crucial for further developments in fuel cell technology. The development of better performance anode electrocatalysts is associated to the introduction of a more oxidizable metal, in order to generate oxygenated species at lower potentials in the vicinity of the Pt active sites to enhance the oxidative desorption of $\mathrm{CO}$ at those sites [9-11].

The feasibility of the use of methanol as primary fuels for proton exchange membrane fuel cells (PEMFC) has been studied and proven by several authors, employing electrodes based on binary electrocatalysts [12-15]. However, less amount of work has been devoted to ternary electrocatalyst systems, which may 
show synergistic effects by the addition to platinum of two metals with similar characteristics.

In this work, the PtRu/C (1/1 at\%), PtDy/C (1/1 at\%) and Pt-Ru-Mo/C (1:1:0.5 and 1:1:1 per cent) electrocatalysts, with and without thermal treatment (TT), have been studied in order to evaluate the electroactivity of Mo and Dy in PEM fuel cells.

\section{Experimental procedure}

The cyclic voltammetry experiment results with the prepared $\mathrm{Pt}-\mathrm{Ru} / \mathrm{C}, \mathrm{PtDy} / \mathrm{C}$ and $\mathrm{Pt}-\mathrm{Ru}-\mathrm{Mo} / \mathrm{C}$ electrocatalysts by the Bönnemann's method in the absence of methanol in a $0.5 \mathrm{~mol} \mathrm{~L}^{-1} \mathrm{H}_{2} \mathrm{SO}_{4}$ solution are presented in Fig.1.

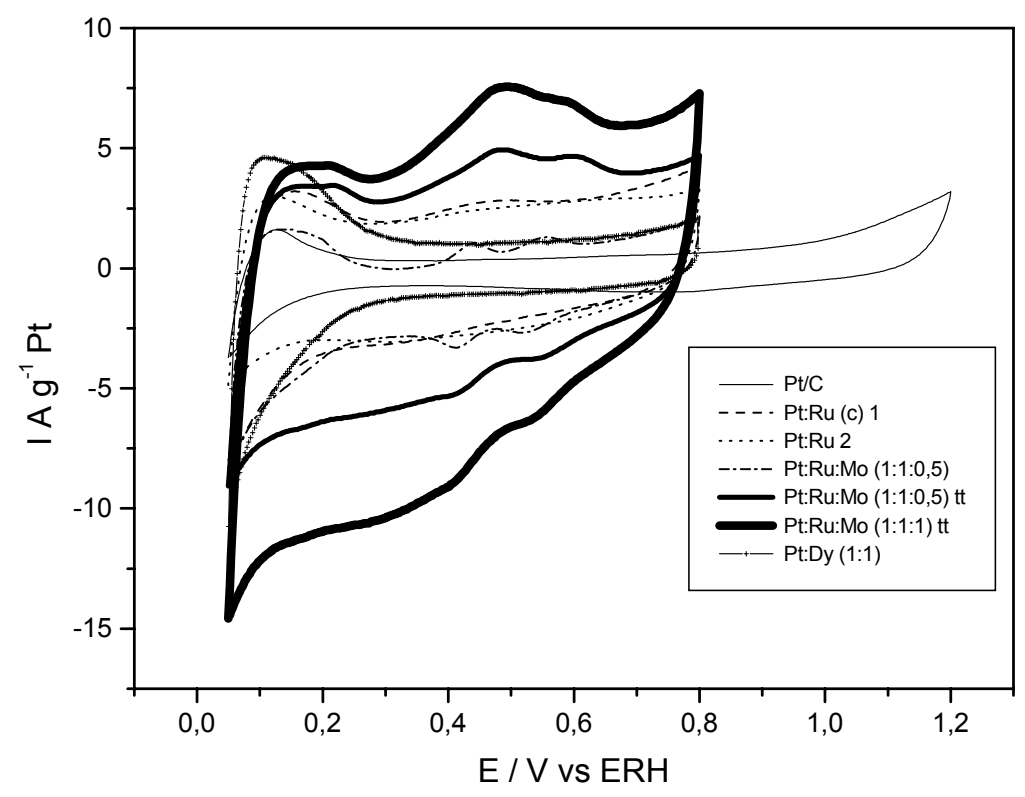

Figure 1. Cyclic voltammograms of $\mathrm{Pt}-\mathrm{Ru} / \mathrm{C}, \mathrm{PtDy} / \mathrm{C}$ and $\mathrm{Pt}-\mathrm{Ru}-\mathrm{Mo} / \mathrm{C}$ electrocatalysts prepared by Bönnemann's method in $0.5 \mathrm{~mol} \mathrm{~L}^{-1} \mathrm{H}_{2} \mathrm{SO}_{4}$ solution by $\mathrm{v}=10 \mathrm{mV} \mathrm{s}^{-1}$.

In the double layer region an increase in the double layer capacity is observed as the content of the second and third metal is increased. In the case of $\mathrm{Ru}$ this phenomenon is related to the formation of oxygenated species at low potentials. 
The same explanation is also valid for Mo, but in this case it is also necessary to consider the oxidation of Mo (see below). In the region of adsorption/dessorption of hydrogen (between $0.0 \mathrm{~V}$ and $0.4 \mathrm{~V}$ ) the corresponding peaks are suppressed due to oxide formation at lower potential than $0.4 \mathrm{~V}$ [18].

The $\mathrm{Pt} / \mathrm{C}$ electrocatalyst curve shows a strong blockade in the hydrogen region. This phenomenon suggests that the electrocatalyst's surface is covered by species from the reducing agent used in Bönnemann's method. Another peak next to $0.5 \mathrm{~V}$ is observed for the $\mathrm{Pt}-\mathrm{Ru}-\mathrm{Mo} / \mathrm{C}$ systems. This peak corresponds to a change in the oxidation state of Mo from +IV to Mo $+\mathrm{VI}$.

Fig. 2 shows cyclic voltammetry curves for Pt/C TT electrocatalysts in the presence of different concentrations of methanol, ranging from 0.1 to $1.0 \mathrm{~mol} \mathrm{~L}^{-1}$, in $0.5 \mathrm{~mol} \mathrm{~L}^{-1} \mathrm{H}_{2} \mathrm{SO}_{4}$.

An increase in the oxidation current is observed, as the methanol concentration increases in potential of $0.8 \mathrm{~V}$.

Figs. 3 and 4 show cyclic voltammetry curves for different electrocatalysts in the presence of different concentrations of methanol, ranging from 0.1 to $1.0 \mathrm{~mol} \mathrm{~L}^{-1}$, in $0.5 \mathrm{~mol} \mathrm{~L}^{-1} \mathrm{H}_{2} \mathrm{SO}_{4}$.

The catalysts present in Figs. 3 and 4 show that increase in current is not proportional to the increase of alcohol concentration in the solution. This behavior indicates a poisoning of the catalyst sites with increasing alcohol concentration due to the adsorption of alcohol on the catalyst surface.

Fig. 5 shows current-potential results for methanol oxidation from $1.0 \mathrm{~mol} \mathrm{~L}^{-1}$ solutions on the different electrocatalysts prepared by Bönnemann's method.

The potential region around $0.5 \mathrm{~V}$ is of great interest for the operational regime of fuel cells operating with the direct oxidation of methanol. In this region the normalized currents may be considered low but it can be observed that Pt-Ru$\mathrm{Mo} / \mathrm{C}$ TT (1:1:1) electrocatalysts present the best results in comparison with those of the other electrocatalysts. This observation indicates that the addition of Mo to Pt-Ru electrocatalysts has a beneficial effect on the oxidation of methanol. 


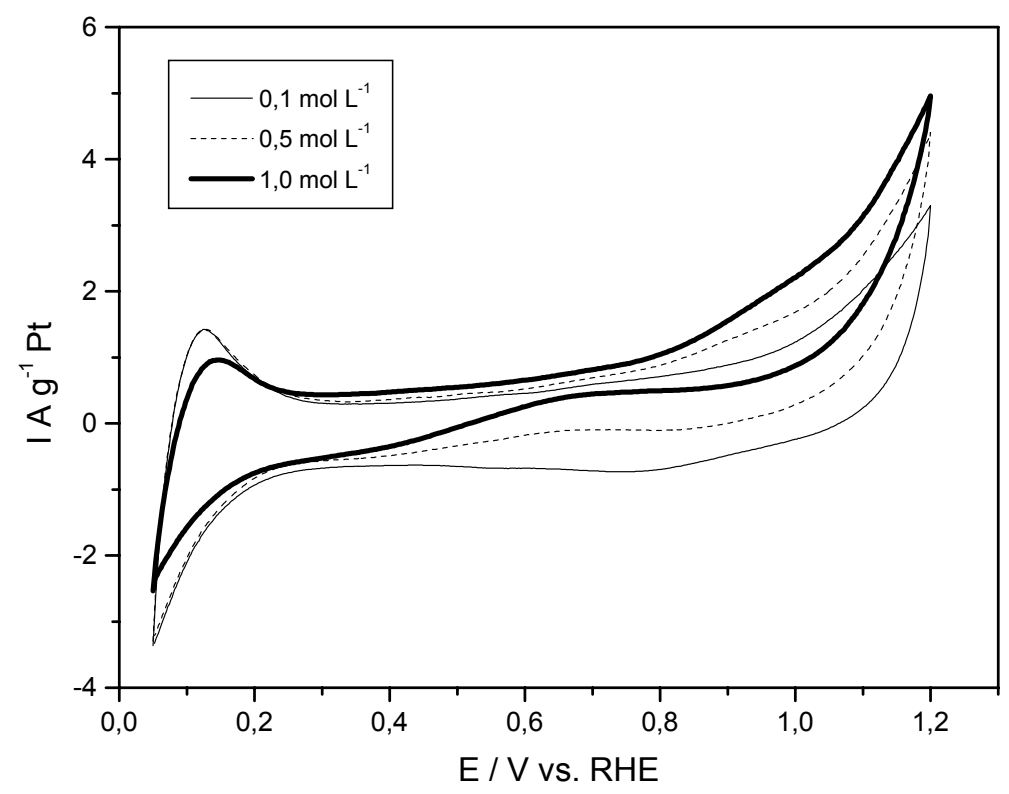

Figure 2. Cyclic voltammograms for $\mathrm{Pt} / \mathrm{C}$ in the presence of different concentrations of methanol between 0.1 and $1.0 \mathrm{~mol} \mathrm{~L}^{-1}$ by $\mathrm{v}=10 \mathrm{mV} \mathrm{s}^{-1}$.

The Pt-Ru-Mo/C TT (1:1:1) shows the best performance, probably because it is less sensitive to the adsorption of methanol at higher concentrations.

The potential region around $0.7 \mathrm{~V}$ is not of interest for the operational regime of fuel cells operating with direct oxidation of methanol. In this potential one can observe that Pt:Dy (1:1) catalysts present best results in comparison with those of the other electrocatalysts. These results indicate that $\mathrm{PtDy} / \mathrm{C}$ is a good catalyst for $\mathrm{CO}$ to $\mathrm{CO}_{2}$ oxidation.

The results in Fig. 5 show the beneficial effects of the thermal treatment at $300{ }^{\circ} \mathrm{C}$ in a hydrogen atmosphere. 

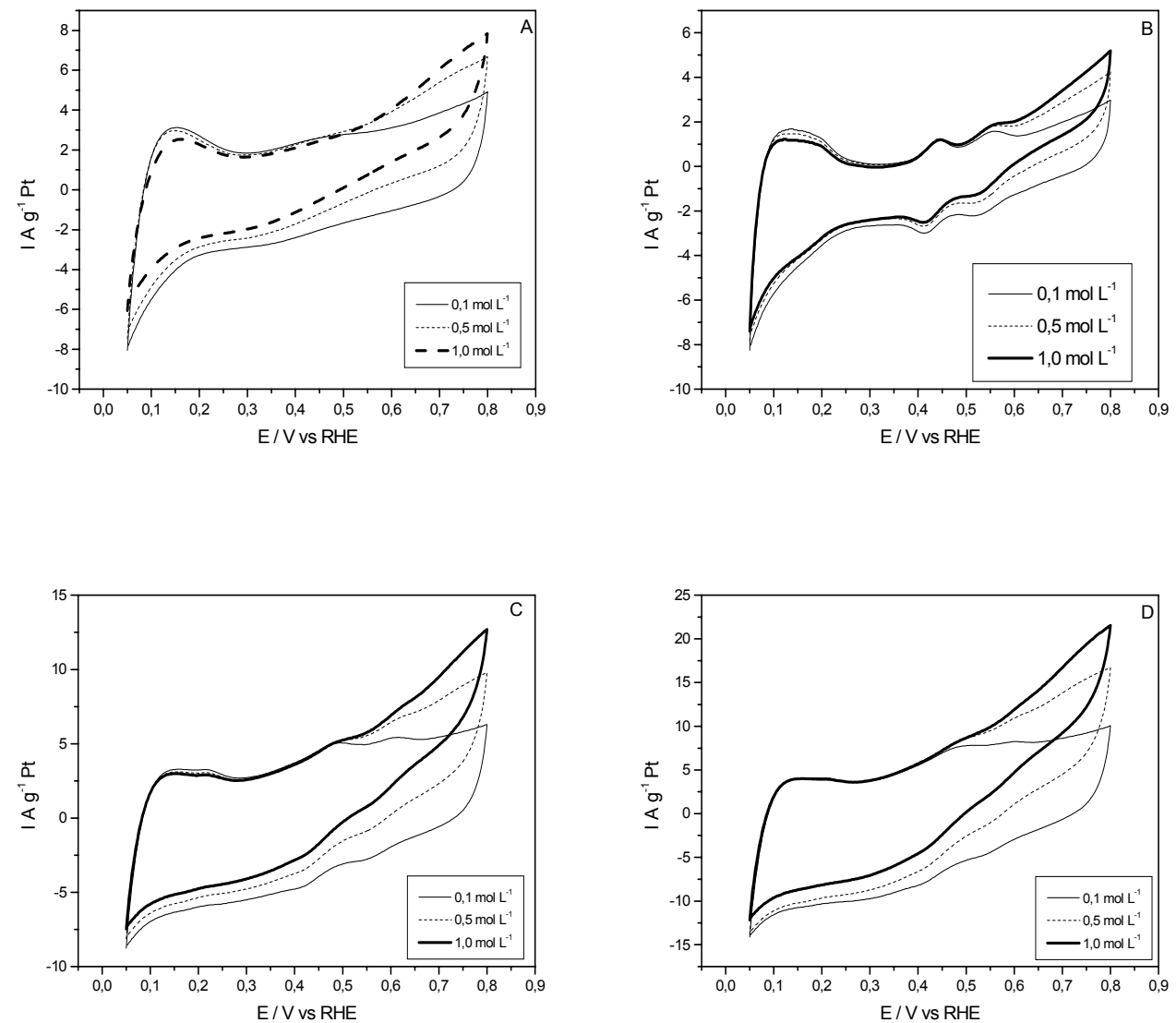

Figure 3. Cyclic voltammograms for (A) Pt:Ru (1:1), (B) Pt:Ru:Mo (1:1:0,5), (C) Pt:Ru:Mo $(1: 1: 0,5) \mathrm{TT}$ e (D) Pt:Ru:Mo $(1: 1: 1) \mathrm{TT}$ in the presence of different concentrations of methanol between 0.1 and $1.0 \mathrm{~mol} \mathrm{~L}^{-1}$ by v $=10 \mathrm{mV} \mathrm{s}^{-1}$.

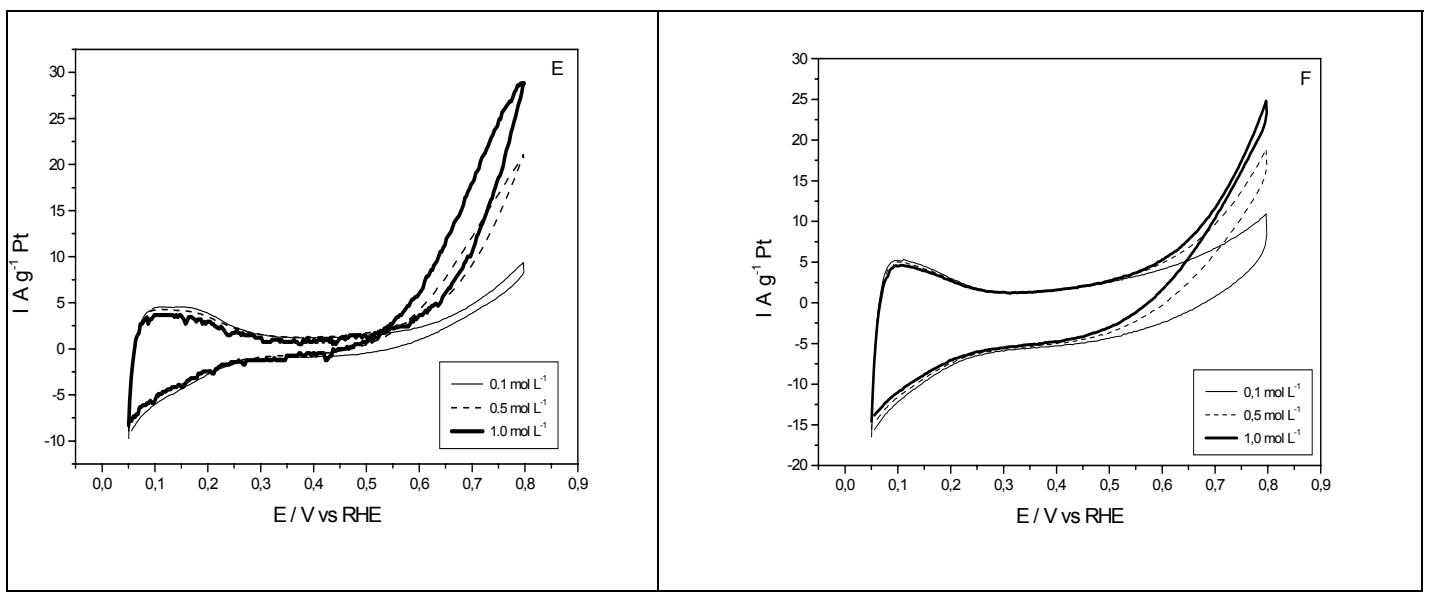

Figure 4. Cyclic voltammograms for (E) Pt:Dy (1:1), (F) Pt:Dy (1:1) TT in the presence of different concentrations of methanol between 0.1 and $1.0 \mathrm{~mol} \mathrm{~L}^{-1} \cdot \mathrm{v}=10 \mathrm{mV} \mathrm{s}^{-1}$. 


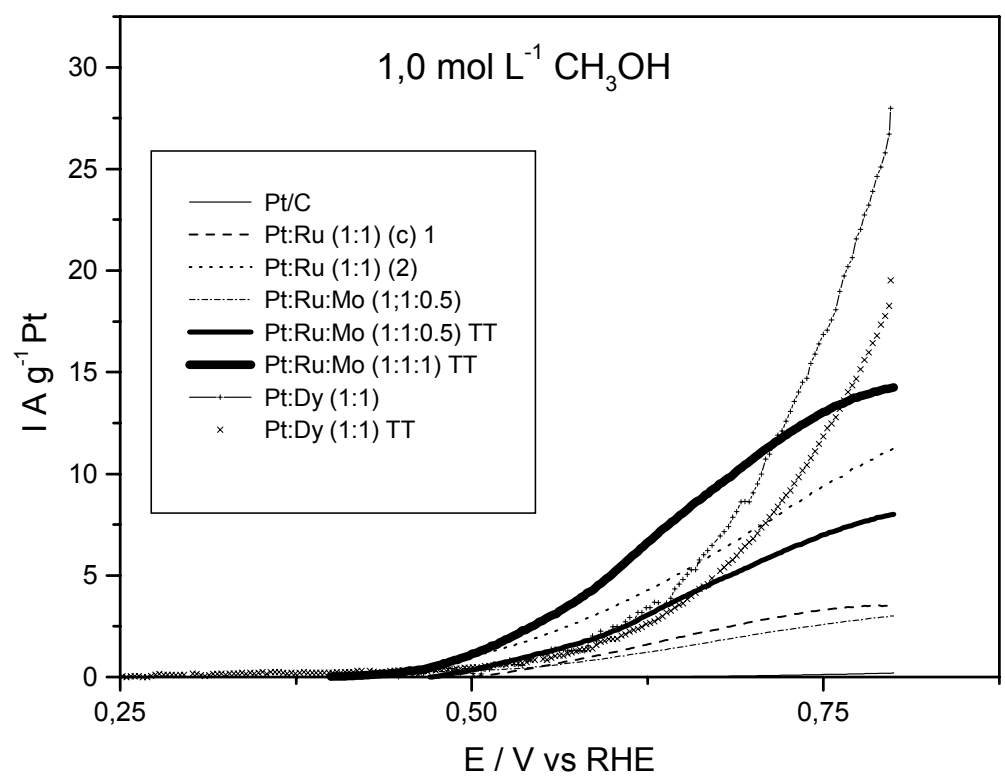

Figure 5. Anodic scans in a $1.0 \mathrm{~mol} \mathrm{~L}^{-1}$ methanol solution with the different electrocatalysts prepared by Bönnemann's method by $\mathrm{v}=10 \mathrm{mV} \mathrm{s}^{-1}$.

\section{Conclusions}

Bönnemann's method showed to be an effective procedure to develop Pt based alloys as active catalyst systems for the oxidation of methanol in PEMFC. The results suggest a considerably enhanced catalyst electroactivity when the catalyst is submitted to a thermal treatment at $300{ }^{\circ} \mathrm{C}$ in a hydrogen atmosphere. The system Pt-Ru-Mo/C TT (1:1:1), submitted to thermal treatment, showed to be very promising for practical application in fuel cells and more active for the oxidation of methanol.

The system Pt:Dy (1:1) showed to be very promising for $\mathrm{CO}$ to $\mathrm{CO}_{2}$ oxidation.

\section{Acknowledgments}

Thanks are due to the Fundação de Amparo à Pesquisa do Estado de São Paulo (FAPESP) and to the Conselho Nacional de Desenvolvimento Científico e Tecnológico (CNPq) for financial support. 


\section{References}

1. H. Wendt, M. Gotz, M. Linardi,. Química Nova 4 (2000) 538-546.

2. P. Berlowitz, Exxon Mobil Research and Engineering in SAE Word Congress Preview, "Global Automotive Network" - SAE International, Issue 11 Feb 2001.

3. M. Faltenbacher, Alternative Fuels for Fuel Cell Powered Buses Compared to Diesel Powered Buses, University of Stuttgart, April 2000, SAE 200001-1484.

4. C.E. Thomas, Societal Impacts of Fuel Options for Fuel Cell Vehicles, Directed Technologies, Inc, October 1998, SAE 982496.

5. J.P.I. Souza, F.J.B.Rabelo, I.R. de Moraes, F.C. Nart, J. Electroanal. Chem. 420 (1997) 17-20.

6. R. Ianniello, V.M. Schmidt, J.L. Rodrigues, E. Pastor, J. Electroanal. Chem. 471 (1999) 167-179.

7. N. Fujiwara, K.A. Friedrich, U. Stimming, J. Electroanal. Chem. 472 (1999) 120-125.

8. H. Hitmi, E.M. Belgsir, J.M. Léger, C. Lamy, R.O. Lezna, Electrochim. Acta 39 (1994) 407-15.

9. A. Oliveira Neto, J. Perez, W.T. Napporn, E.A. Ticianelli, E.R. Gonzalez, Electrooxidation of methanol on binary platinum based catalysts. in Workshop Electrocatalysis in Indirect and Direct Methanol PEM Fuel Cells, 3rd International Symposium in Electrocatalysis. Portoroz, Slovenia, 1999, 83-6.

10. N. Fujiwara, K.A. Friedrich, U. Stimming, J. Electroanal. Chem. 472 (1999) 120-125.

11. A. Oliveira Neto, M.J. Giz, J. Perez, E.A. Ticianelli and E.R. Gonzalez, J. Electrochem. Soc. 149 (2002) A272-A279.

12. C.T. Hable, M.S. Wrighton, Langmuir 9 (1993) 3284-90.

13. J. Wang, S. Wasmus, R.F. Savinelli, J. Electrochem. Soc. 142 (1995) 421824.

14. M. Gotz, H. Wendt, Eletrochim. Acta 43-24 (1998) 3637. 
15. E.G. Franco, M. Linardi, E. Aricó, Proceedings of the XII SIBEE Simpósio Brasileiro de Eletroquímica e Eletroanalítica, Gramado - RS - Brasil (2001).

16. A. Oliveira Neto, Estudos Eletroquímicos sobre Eletrocatalisadores a Base de Platina Dispersos em Carbono de Alta Área Superficial, PhD Thesis, University of São Paulo, Brazil, 2001.

17. A. Oliveira Neto, J. Perez, W.T. Napporn, E.A. Ticianelli, E.R. Gonzalez, J. B. Chem. Soc. 11, N1 (2000) 39-43.

18. T.J. Schimidt, H.A. Gasteiger, R.J. Behm, Eletrochem. Communications 1 (1999) $1-4$. 